\title{
O.CRUM AD. 15 AND THE EMERGENCE OF ARABIC WORDS IN COPTIC LEGAL DOCUMENTS ${ }^{1}$
}

\author{
Tonio Sebastian Richter
}

The Coptic language has commonly been considered to be hospitable to foreign words. ${ }^{2}$ This was certainly true in the case of borrowing from Greek, to an extraordinarily high degree, but it was not at all true of borrowing from Arabic. In some respects, the contact between Coptic and Arabic may be compared with that of Demotic and Greek in Ptolemaic and Roman times. Under similar conditions of an increasingly bilingual milieu in the realm of spoken language, written Egyptian nevertheless was restricted by its proper decorum to using indigenous vocabulary, avoiding foreign words to the greatest possible extent. As is well known, interference of the Greek and Egyptian languages would result from longterm bilingualism, its striking evidence being Coptic as a fully functional language enriched by an enormous amount of Greek vocabulary drawn from most semantic and grammatical catagories.

On the contrary, the colloquial absorption of Arabic, contrary to what might be expected (since it finally led to almost complete language replacement), scarcely left any trace in Coptic texts. If we want to investigate the when, where and why of borrowing Arabic words in the Coptic written language, we must exclude a considerable segment of Coptic literary production. Not only canonical texts, with their (intended) unchangeableness more or less perfectly maintained by scrupulous copying (e.g. biblical texts), but also literary genres handed down in much more open manuscript traditions (e.g. homilies), and even entirely new late Coptic compositions (e.g. those

1 This article summarizes two papers read at the Cairo colloquium, I am deeply indebted to Lennart Sundelin who improved the English of the printed version. For the issues dealt with, cf. also: T. S. Richter, "Arabische Lehnworte und Formeln in koptischen Rechtsurkunden," fJP 31 (2001), 75-98, and id., "Koptische Mietverträge über Gebäude und Teile von Gebäuden," ffP 32 (2002), 113-68.

${ }^{2}$ As pointed out by G. Mink, "Allgemeine Sprachwissenschaft und Koptologie," in R. McWilson (ed.), Coptic Studies, vol. I: The Future of Coptic Studies, Leiden 1978, 71-103, esp. 95 f. 
of the so-called folk literature), ${ }^{3}$ show no linguistic features that might be due to the influence of Arabic. In fact, Coptic literature, in the proper sense, clearly remained untouched by the phenomenon of linguistic interference up until the time when the concerned texts were translated into Arabic. ${ }^{4}$ Also, in some types of everday texts (e.g. epigraphic formularies), there is a continuing use of traditional patterns of expression for a very long time. All these mentioned kinds of Coptic texts have their pragmatic scope (Sitz im Leben) in common. They are closely connected with the religious life and customs of Christian communities, that is, with a quite homogenous milieu of culture and language.

Of course, traces of Coptic-Arabic interference might instead be expected in Coptic texts pragmatically embedded in those segments of everyday life that included cultural and linguistic contact. Obviously, it was semantic emergency - the simple lack of suitable designations being "a universal cause of lexical innovation"5 - which would have given rise to the adoption of Arabic words in written Coptic. To the best of my knowledge, the earliest evidence of a strong Arabic influence is attested by a group of educational and scientific Coptic manuscripts from around the ninth and tenth centuries. ${ }^{6}$ There are Arabic names for drugs and diseases recorded in Coptic transcription in a large medical papyrus, ${ }^{7}$ likewise in an alchemical treatise Arabic names of organic and inorganic substances appear. ${ }^{8}$ Despite the former existence of an elaborated Egyptian astronomical terminology still attested in late Roman times, ${ }^{9}$ planets and constellations bear Arabic names in Coptic astrological tracts, ${ }^{10}$ and a Coptic cal-

${ }^{3}$ A. Erman, Bruchstücke koptischer Volkslitteratur, Berlin 1897, and H. Junker, Koptische Poesie des 10. Jahrhunderts, Teil 1-2, Berlin 1908-11.

${ }^{4}$ For this period of language shift, see S. Rubenson, "Translating the Tradition: Some Remarks on the Arabization of the Patristic Heritage in Egypt," Medieval Encounters: Jewish, Christian and Muslim Culture in Confluence and Dialogue 2 (1996), 4-14.

${ }^{5}$ U. Weinreich, Languages in Contact, The Hague/Paris 1968, 56.

${ }^{6}$ Cf. W. H. Worrell, "Testimony of Arabic Words in Coptic in the Ninth or Tenth Century," in Coptic Sounds, Ann Arbor 1934, 122-33.

${ }^{7}$ É. Chassinat, Un papyrus médical copte, Mémoires publiés par les membres de l'Institut français d'archéologie orientale du Caire 32, Cairo 1921.

${ }^{8}$ L. Stern, "Fragment eines koptischen Tractates uber Alchimie," ZÄS 23 (1885), 102-19.

${ }^{9}$ See e.g. A. von Lieven, Der Himmel über Esna, ÄA 60, Wiesbaden 2000.

${ }^{10}$ E.g. Codex Parisinus 135,5 quoted by Oskar von Lemm, Der Alexanderoman bei den Kopten, St. Petersburg 1903, 35f., and a text published by Pierre Bouriant, "Fragment d'un manuscrit copte de basse époque ayant contenu les principes 
culation manual provides Arabic units of measure and calculation terms in Coptic transcription. ${ }^{11}$ The strikingly high presence of Arabic borrowings in these manuscripts might have been due to the inevitablity of using appropriate nomenclature in order to participate in contemporary scientific discourse to some extent comparable with the use of languages for special purposes in modern sciences. Such terms of nomenclature clearly differ from 'ordinary' appellativa by their specifically close connection between signifié and signifiant. Just as with proper names, they cannot be simply translated from one language into another one; not, at least, as easily as conceptual terms like 'man', 'to make', 'beautiful', 'three', or 'in'.

The approach taken in this paper attempts to describe and to interpret the emergence of Arabic borrowings in Coptic legal documents. First I will provide a new edition of the Coptic ostracon O.Crum Ad. 15. Although known for a long time, it has not fully been appreciated until now - since it bears hitherto undetected evidence for a semantic calque inspired by the Arabic. My second approach will refer to early borrowed Arabic loanwords, attested in Coptic legal documents from about the late seventh century up to the middle of the ninth century. And last I will attend to the late Coptic Teshlot archive (eleventh century) and its Arabic borrowings.

\section{O.Crum Ad. 15: A Re-Edition}

The Coptic ostracon O.Crum Ad. 15 belongs to the collection of the Egyptian Museum of the Leipzig University, bearing inventory number $504 .^{12}$ It measures $9 \mathrm{~cm}$ in height and $12 \mathrm{~cm}$ in width. Acquired by Georg Steindorff at Luxor, ${ }^{13}$ some of its dialectal features support the assumption that it really originates from the Theban area. It was published already in 1902 in the pioneering work Coptic Ostraca

astronomiques des arabes," foumal Asiatique, deuxième série, tome IV, Paris 1904, 117-23.

1 BL Or. 5707 published by James Drescher, "A Coptic Calculation Manual," BSAC 13 (1948-49), 137-60; republished by M. R. M. Hasitzka and H. Harrauer, Neue Texte und Dokumentation zum Koptisch-Unterricht, MPER n.s. 18, Vienna 1990, no. 331.

${ }^{12} \mathrm{I}$ am very grateful to the authorities of the Ägyptisches Museum der Universität Leipzig, Prof. Dr. Hans-W. Fischer-Elfert and Dr. Friederike Kampp-Seyfried, for kindly permitting me to publish this new edition of Inv.-Nr. 504.

${ }^{13}$ This is the only information provided by the old card-index of the collection. 
by Walter Ewing Crum. ${ }^{14}$ The text is written on a smooth potsherd of light reddish clay, quite different from the well-known grooved pottery of brownish colour serving as writing support for the great majority of Coptic ostraca from Thebes. The handwriting of the text is a fluent cursive (see plate 7), most easily comparable with that of the Theban tax receipts. Thus, palaeography would suggest a dating early in Islamic times, in the first half of the eighth century rather than in the late seventh. The ostracon contains a lease contract concerning a house. ${ }^{15}$

Text

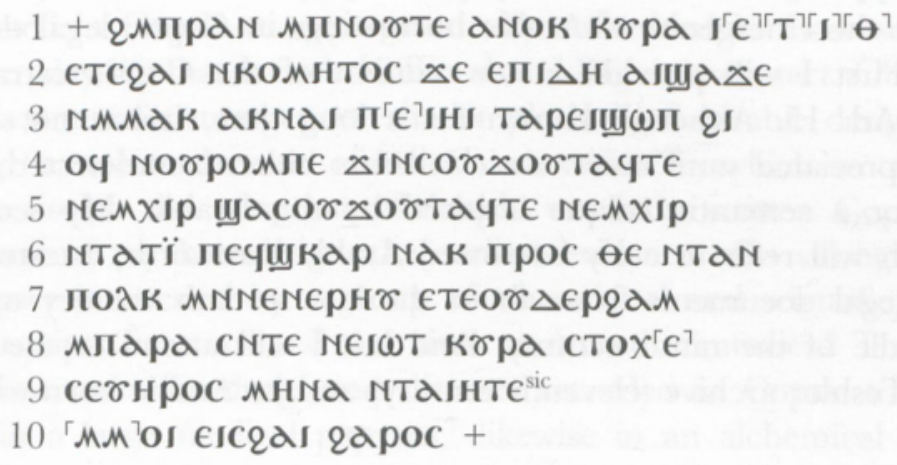

2 комнтос: Crum комєтос - 8 стохє: $\operatorname{read}$ сто $<\mathbf{I}>\boldsymbol{\chi} \epsilon-9$ NTAIHTE: $\operatorname{read}$ NTA $<$ C $>$ HTE

\section{Translation}

1 In the name of God! at is I, Kyra, (daughter of) Ietith, 2 who writes to Komêtos ${ }^{\mathrm{a}}$ : ${ }^{\mathrm{b}} \mathrm{Since}\left(\dot{\varepsilon} \pi \varepsilon 1 \delta\right.$ '́) I have spoken 3 with you ${ }^{\mathrm{b}}$, 'you (gave) $\mathrm{me}^{\mathrm{c}}{ }^{\mathrm{d}}$ this house, ${ }^{\mathrm{e}}$ so that I dwell on $4 \mathrm{it}^{\mathrm{e}} \mathrm{f}^{\mathrm{one}}$ year from day twenty-four of Mechir 5 until day twenty-four of Mechir; 6 gand I give you its rent in the manner ( $\left.\pi \rho \rho_{\varsigma}\right) 7$ we had settled with each other $^{\mathrm{g}}$, hbeing one dirham 8 less ( $\pi \alpha \rho \alpha$ ) two (corns of) barley ${ }^{\mathrm{h}}$. Kyra

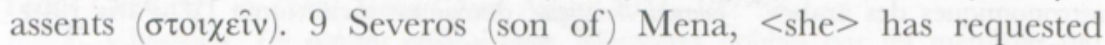

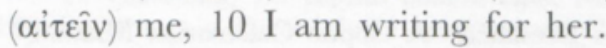

\footnotetext{
14 W. E. Crum, Coptic Ostraca, London 1902 (editio princeps, Ad. 15, and translation, p. 23). See also the translation by W. C. Till, Die koptischen Rechtsurkunden aus Theben, Vienna 1964, $69 \mathrm{f}$.

${ }^{15}$ For Coptic leases of houses generally, see Richter, "Koptische Mietverträge".
} 


\section{Commentary}

a-a The address formula mentions the parties: The tenant, issuing the record, is a woman. She says: "I, Kyra Ietith", and this was considered by Crum and Till as being her title ('lady') and her name (Ietith). For two reasons I don't agree with them. First, in an overwhelming majority of instances in Coptic the honorific title $\kappa u ́ \rho \alpha$ 'lady' bears an article: Т-кrрd 'the lady'. ${ }^{16}$ Furthermore, in line 8, when the issuing party's consent is finally expressed, the text reads: кrрd сто(I)X€ "Kyra is assenting". Since кrрd is well attested as a female personal name, an emendation of the name IєTा line 8 as suggested by Crum and Till seems unnecessary. Most probably, the name of the tenant is "Kyra, (daughter of) Ietith" (the mother's name to be considered a phonic variant of the Septuaginta form Iov $\delta \varepsilon \dot{\theta} \theta$ ). In line 9, the scribe of the text has written his own name in this very manner of asyndetic junction ("Severos (son of) Mena"), and in line 2 the name of the lessor Komêtos appears just like that of Kyra in line 8 without mentioning the filiation. Concerning the gender of the contract parties attested in leases of houses, already in 1913 Berger wrote: ${ }^{17}$ "Es ist auffallend, wie oft in den Mietverträgen Frauen, sowohl als Vermieterinnen als auch als Mieterinnen... auftreten." Recently Hansgünter Müller calculated the proportion of those contracts involving women as tenants, lessors or both, at onesixth in Principate times, increasing to a third during the Byzantine period. ${ }^{18}$ Obviously this feature is shared by the Coptic contracts. In four of the twelve texts preserved, women are acting either as tenant (O.Crum Ad. 15) or lessor (CPR IV 113 and O.Hall 73/2), or even as both tenant and lessor (as in CPR IV 114).

b-b The deed corpus is beginning here with the word $\epsilon \Pi \mathbf{I} \Delta \boldsymbol{H}$,

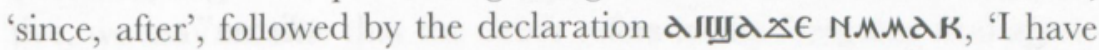
spoken with you'. Assuming that these two words alone constitute a kind of 'clause', one may recall the Greek hypomnemata-contracts, attested until the sixth century, which were stylized as a request or 58,20 .

${ }^{16}$ Cf. e.g. O.Crum 169,2; 205,2; 268,2; 289,13; 320,5.6; Ad. 25,10; Ad. 28,2; Ad.

${ }_{17}$ A. Berger, "Wohnungsmiete und Verwandtes in den gräko-agyptischen Papyri," in Zeitschrift für vergleichende Rechtswissenschaft 29 (1913), 321-415.

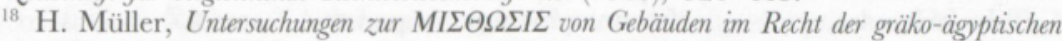
Papyri, Erlanger Juristische Abhandlungen 33, Köln/Berlin/Bonn/Munich 1985, 102-9; for the whole subject, cf. A. Arjava, Women and Law in Late Antiquity, Oxford 1998. 
an offer to lease. ${ }^{19}$ At the very least, a prior consultation of the parties might explain the laconic wording of our document.

${ }^{c-c}$ The acknowledgement of the issuing party: "you have (given) to me this house" is lacking the verb $f$ 'to give' due to a peculiarity of Coptic texts from Thebes already noticed by Walter Crum. ${ }^{20}$ The phenomenon was also discussed by Stephen $\mathrm{Emmel}^{21}$ and most recently by Leo Depuydt. ${ }^{22}$ As is shown by all examples, it depends on a certain syntactic environment, consisting of a tri-partite conjugation base (permitting the use of reduced infinitive forms) ${ }^{23}$ and a direct object closely junctured although seperated from the conjugation by a pronominal dative form, e.g.:

\begin{tabular}{|c|c|c|c|}
\hline O.Crum 157,4 & NTd & мНК обтермНСІом & $\begin{array}{l}\text { "that I (give) you } \\
\text { a trimesion" }\end{array}$ \\
\hline O.Crum 244,4 & $d K$ & мнІ огнр & $\begin{array}{l}\text { "how much did } \\
\text { you (give) me?" }\end{array}$ \\
\hline O.Crum 403,5 & млог & мнІ лгохоко/ & $\begin{array}{l}\text { "they did not (give) } \\
\text { me the solidus" }\end{array}$ \\
\hline,- 9 & Nए & МН ЛКєога & $\begin{array}{l}\text { "and you (give) the } \\
\text { another one" }\end{array}$ \\
\hline O.CrumST 40,16 & ЕМЛI & NEK COr & $\begin{array}{l}\text { "while I did not } \\
\text { (give) them to you" }\end{array}$ \\
\hline O.CrumST 129,2 & 24 & NHI NO K3 & $\begin{array}{l}\text { "you (gave) me } 27 \\
\text { no(mismatia)" }\end{array}$ \\
\hline,- 3 & 24 & NHI обтєрМЕСЕОN & $\begin{array}{l}\text { "he (gave) me a } \\
\text { trimesion" }\end{array}$ \\
\hline,- 4 & 24 & мнм мNтХємNаттр & $\begin{array}{l}\text { "he (gave) us } \\
\text { thirteen(?) litron" }\end{array}$ \\
\hline,- 5 & 24 & мнN мач NAттр & $\begin{array}{l}\text { "he (gave) us thirty } \\
\text { litron" }\end{array}$ \\
\hline
\end{tabular}

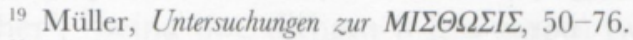

${ }^{20}$ W. E. Crum, Short Texts from Coptic Ostraca and Papyri, Oxford 1921, viii.

${ }^{21}$ S. Emmel, "Proclitic Forms of the Verb + in Coptic," in D. W. Young (ed.), Studies Presented to Hans Jakob Polotsky, E. Gloucester (Mass.) 1981, 131-46.

${ }^{22}$ L. Depuydt, "Eight Exotic Phenomena of Late Egyptian Explained," in K. Ryholt (ed.), Acts of the Seventh International Conference of Demotic Studies, Copenhagen, 23-27 August 1999, CNI Publications 27, Copenhagen 2002, 122.

${ }^{23}$ In one case, at least, the unetymologic imperative form $T(\mathbf{I})$ - seems to be attested also: O.CrumST 331,11-12, тепог мач хогшт поєIK "Now (give) him twenty breads". 


\begin{tabular}{|c|c|}
\hline $\begin{array}{lll}- & -, 7 & d y\end{array}$ & 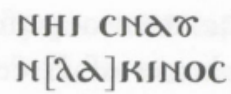 \\
\hline O.CrumST 219,2f. Td & $\begin{array}{l}\text { мнК таIIє } \\
\text { мершім }\end{array}$ \\
\hline
\end{tabular}

"he (gave) me two bottles"

"and I (give) you the oipe of lentils"

The conclusion drawn by Depuydt is that the entirely reduced infinitive form $\boldsymbol{T}$ - followed by the dative particle $\boldsymbol{N}$ - was suffering from a 'nasal plotion'. This exotic phenomenon of a 'zero lexeme' (since there is no elliptic omission but an invisible presence of the verb) recalls a similar one preserved in Coptic letters from Kellis, Dakhleh Oasis where a reduced-form spelling of the dative preposition is attested, depending on similar syntactic conditions, e.g. P.Kell.Copt

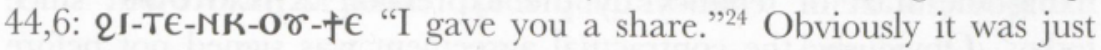
this wide-spanned extension of the single prosodic unit acrossing the post-infinitival dative preposition down to the directly linked object noun phrase ${ }^{25}$ (only possible with the verb $f$ 'to give') which caused the reduction of the dative preposition in Kellis as well as the reduction and following 'nasal plotion' of the verb $f$ in Thebes. In the present lease contract of O.Crum Ad. 15, the 'zero verb' $f$ 'to give' does not mean 'I bestow' or 'I sell', but as connoted by context only, it just means 'I lease' (to you). Such a rather terse expression in order to say 'I lease' is elsewhere attested in Coptic lease contracts both from Middle Egypt ${ }^{26}$ and from Thebes: $\epsilon \mathbf{I}+\mathbf{N} \boldsymbol{K}$, literally "I give you." 27

$\mathrm{d} d \mathrm{~d}$ The material object of the lease as well as the grammatical object of the unvisible verb 'to give' is $\boldsymbol{л} \boldsymbol{\epsilon} \mathbf{I} \mathbf{I}$ "this house." The strong determination by the demonstrative article seems strange, since there is no further mention of "this house," neither before nor after this one. If we do want to interpret the choice of the demonstrative, we may assume that the deixis refers to the foregoing oral agreement of the parties mentioned above.

${ }^{\mathrm{e}-\mathrm{e}}$ After recording the fact of leasing and its object, this clause designates the purpose intended by the tenant. Such a clause is

${ }^{24}$ I. Gardner, A. Alcock, and W.-P. Funk, Coptic Documentary Texts from Kellis, Dakhleh Oasis Project Monograph 9, Oxford 1999.

${ }^{25}$ Description according to the analysis by W.-P. Funk in Gardner et al., Coptic Documentary Texts from Kellis, 87.

${ }^{26}$ Cf. T. S. Richter, "Alte Isoglossen im Rechtswortschatz koptischer Urkunden," Lingua Aegyptia 10 (2002), 389-99.

${ }_{27}$ A Theban example being e.g. O.Crum 139,4. 
attested also in Coptic lease contracts from Hermopolis, ${ }^{28}$ corresponding to the recurrent phrase of Greek house leases "I confess to have leased from you for the time you want, starting up on day

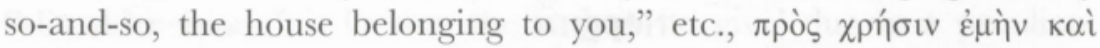

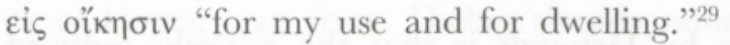

f-f Here the period and start of the tenancy are recorded. But the text does not bear the date of issue, thus we cannot know the interval between the day of recording the contract and the date of the contract coming into force. ${ }^{30}$ Among the Hermopolite Coptic leases, there are three texts preserving complete clauses about term of tenancy (BKU III 426; CPR IV 114, P.Lond.Copt. I 1018), all of them fixing the start of tenancy by the expression хाммлоо 'since today'. Obviously, the contractual agreement was signed not before the first day of its validity. The term of one year seems to have been a common space of time for lease agreements so far attested in Coptic. On the contrary, Greek contracts from the Byzantine

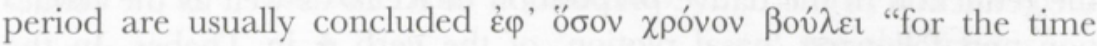
you (i.e. the lessor) want." 31

g-g The last clause is dealing with the payment. The word expressing the term 'rent' is шкар. The use of the word Шбор, шкар or $\boldsymbol{U K}$ Kdap within the Coptic terminology of leases corresponds to that of the Greek word غ́voíkıv, ${ }^{32}$ both words designating payment for simple use of rented objects, without a tenant's goal being to make profit by using the leased object.

${ }^{\mathrm{h}-\mathrm{h}}$ Of course, the amount of rent is an essential point of every lease contract. ${ }^{33}$ Thus, the last point made by our contract just con-

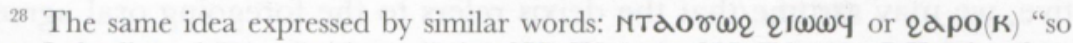
that I dwell on it" (or "with you") in CPR IV 114, CPR IV 115, P.HermitageCopt. $1+$ and P.Lond.Copt. I 1018; cf. Richter, "Koptische Mietverträge."

${ }^{29}$ Cf. Müller, Untersuchungen, 241-4; Berger, "Wohnungsmiete," $341 \mathrm{f}$.

${ }^{30}$ For the Greek evidence, see Berger, "Wohnungsmiete," 373-6.

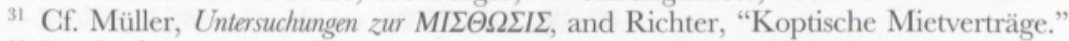

${ }^{32}$ Re évoíkıv, cf. A. Berger, "Wohnungsmiete," 342-8. In Coptic land leases, the leaseholders have to pay шом in the Fayyum and лактом in Thebes. In Ashmunein, where emphyteusis as a third type of lease was usual, the Coptic words used for the different kinds of payment are фुopoc to be paid by leaseholders, Лактом to be paid by hereditary leaseholders and шбор to be paid by tenants; cf. Richter, "Alte Isoglossen."

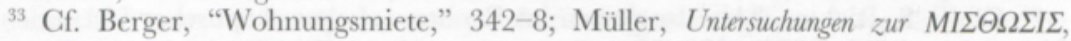
118-226; K. A. Worp, "Bemerkungen zur Höhe der Wohnungsmiete in einigen Papyri aus dem byzantinischen Ägypten," Tyche 3 (1988), 273-5. 


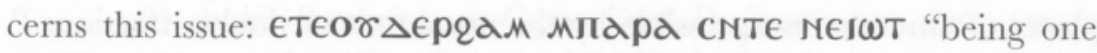
dirham Ллрд two $€ \mathbf{I} \omega \mathbf{T}$." Here we meet the Arab silver currency, the dirham, in quite an interesting phrase. The following Greek loan word Лдpd has at least three somewhat different meanings in Coptic $^{34}$ - a remarkable semantic polyvalency of a preposition borrowed from another language. Two of them are attested in Coptic literary and non-literary texts as well. The third one seems to be restricted to non-literary Coptic:

\section{Irapd in Coptic}

1 more than, beyond plus que, au-delà mehr als, über... hinaus

e.g. O.Crum 370,5-6: шачваре ммом лард магкалом "he is burdening us more than is fair"

2 contrary to, against malgré, contre gegen, entgegen

e.g. O.Crum 40,4f: алкш латош мсшг алвшк єкєтош лара мкаNФм "I left my district, I went to another district contrary to the rules"

3 less moins weniger

e.g. O.Crum 405,3-5: огеодок/ мпогв ... млард кєрат/ "оnе gold solidus ... less a keration"; O.Crum 462,3v: ... .] Г̄ртов лара слтє мидає "x artabas less two maje"

The second meaning is not quite different from the first one, since it denotes the idea of 'beyond' with a specific reference to binding norms or generally accepted ideas. However, the third meaning seems to be contradictory to the first one. The Egyptian dry measure unit called maje was a fraction of an artaba, just as the keration was a fraction of the solidus. Evidently, the third meaning is necessarily connoted just in such a manner by two different amounts of measures, coins, or the like. Thus, in appropriately connoted phrases, the word Лара functions in Coptic documents just as in Greek ones, where the so-called $\pi \alpha \rho \grave{\alpha}$-formula commonly expresses decimal

${ }^{34}$ All of them originally belonging to the accusative formation of this preposition, and all of them still attested in modern Greek. 
places of amounts inexpressible by the usual unit or double fractions. ${ }^{35}$ As for the the Iapd-formula denoting the rent to be paid by Kyra daughter of Ietith there is a problem, however. The homonymous Coptic word $\epsilon \mathbf{I} \omega \mathrm{T}$ either means 'barley' or 'father'. As a matter of course, the latter may be left out of consideration. But even the meaning 'barley' seems hardly suitable at first glance. What shall we understand by "two barley," and how might they be subtracted from one dirham? That is why both Crum and Till suspected a corruption of the text. Walter Crum translated in his edition in Coptic Ostraca "1 dirham of barley less 2 ...," presuming a lack of any unit defining the second amount. ${ }^{36}$ Walter Till translated the phrase under discussion as "namely one dirham less 2 (.. .) barley," suspecting a measure of capacity omitted. ${ }^{37}$ However, it seems possible to understand the written text well without any emendation. Colleagues working on Arabic documents may already have guessed the solution. In Arabic, the smallest unit used for adjusting and weighing coins is called habba 'corn of barley'. Writers like al-Maqrīzī counted in habba for refering to different standards of the dirham. In fact, the Arabic papyri also do so when mentioning fractions of the dirham or pointing out the several standards of currency.

Thus, the precise meaning of $\epsilon \mathbf{I} \boldsymbol{\omega} \mathbf{T}$ 'barley' in O.Crum Ad. 15 obviously depends on the special semantic value 'corn of barley (as counting unit)', passing from the Arabic word habba to its Coptic synonym. Our documentary witness for this semantic calque (Lehnbedeutung) gets support from the evidence of Ms. British Library Or. 5707, an elaborate educational text written about A.D. 900. Among its counting exercises, there also occur some examples of monetary conversion, reducing $60 € \mathrm{E} \omega \mathrm{T}$ into one keration and $1440 \mathrm{\epsilon I} \omega \mathrm{T}$ into one holokottinos. So, we may well translate the rent amount in O.Crum Ad. 15, line 7-8, as "one dirham less two habba."

${ }^{35}$ For the avoidance of such a use of лдрд in literary Coptic; compare 2 Cor

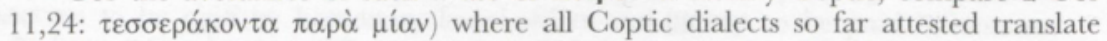

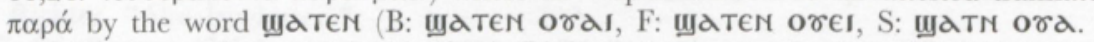

${ }_{36}$ The entry "as rent" in his Coptic Dictionary (s.v. €IWT 'barley', CD 87b) is due to that conjecture.

37 Till, Die koptischen Rechtsurkunden aus Theben, 70. 


\section{Arabic Borrowings in Coptic Legal Documents from the Late Seventh to the Mid-Ninth Century}

The appearance of a semantic calque in an eighth-century Coptic documentary text raises the issues of when, where and why the reception of Arabic borrowings in Coptic took place. Dealing with Coptic legal documents from the first two centuries of Arab rule over Egypt, anyone trying to answer this question must operate with very scarce evidence. During the main period of issuing legal documents in Coptic, the contact between Arab authorities and their subjects left only minimal traces in the written language. In fact, only two Arabic words do occur with any considerable frequency. One of them is the word a m.pd. ${ }^{38}$ As is well-known, it depends on the Arabic word $a m \bar{r}$, literally meaning 'commander' but frequently used as an epithet for officials like the pagarchos/șăhib al-kūra. ${ }^{39}$ However, the most often attested Coptic form is spelled with the final vocal alpha. Further, the penultima of the word is vocalized sometimes with alpha (amapd) or epsilon ( $\mathbf{d} M \in \mathbf{p d}$ ), a reduction resulting from the shift of stress on the last syllable. These features clearly indicate that the Coptic loan word has not been borrowed from Arabic directly. More likely, Coptic adopted the Greek form $\dot{\alpha} \mu$ เ $\hat{\alpha} \varsigma$, especially the dative and vocative form $\dot{\alpha} \mu$ เ $\hat{\alpha}$ commonly used in address formulae. The linguistic constellation attested in the famous trilingual Aphrodito dossier from the beginning of the eighth century may explain why this word has taken such a circuitous route from Arabic to Coptic. ${ }^{40}$ As is well known, in the office of the governor Qurra ibn Sharik, at the highest administrative level, documents were written in Arabic and also in Greek, depending on the addressee. At a lower level of administration, that of the pagarch of Aphrodito, both Arabic and

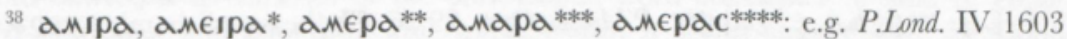
(A.D. 709, Aphrodito); P.KRU passim (Thebes), O.Med.Habu 281,5 (a tax called пєZємгом мламгра); O.Vindob.Copt. 384,8; P.Ryl.Copt. 115,6; 132,2; and passim**; 373***; 374**; 381,10*****; CPR IV 51,8 (Ashmunein); P.Bal. 122,5; 183,3; 184,1; $187,11^{* * *} ; 242,4^{* * *}$.

${ }^{39}$ Cf. A. Grohmann, "Der Beamtenstab der arabischen Finanzverwaltung in Ägypten in früharabischer Zeit," in Festschrift Friedrich Oertel, Bonn 1964, 120-34.

${ }_{40}$ For the Qurra correspondence (P.Lond. IV, P.Ross.Georg. IV, etc.), see H. Cadell, "Nouveaux fragments de la correspondence de Kurrah ben Sharik," Recherches de Papyrologie 4 (1967), 107-60. For our subject, see also A. Grohmann, "Griechische und lateinische Verwaltungstermini im arabischen Ägypten," CdE 13-14 (1932), 275-84. 
Greek were used, too. Only some local administrative bodies in the villages made use of Coptic. Thus, in communication between Arabicspeaking authorities and Coptic-speaking subjects about matters of tax revenue, mustering workmen, the administration of justice, and the like, Greek served as the lingua franca.

Another early attested Arabic word is dirham, the designation for the Arab silver currency, in Coptic as $\Delta € p q \alpha \mu, \tau \in p q \alpha M$ and similar. When the Arab gold coin, the dinār, was established in Egypt about $697,{ }^{41}$ the common Coptic designation holokottinos simply shifted from the Byzantine solidus to the dinār, especially since the new golden coin resembled the older one in size and weight. With respect to silver currency, however, in the coinage reform of the emperor Anastasius in 498 a heavy copper coin called follis and its fractions were put into circulation and minted silver was more and more driven out of circulation in the Byzantine empire. Only as units of account did a few silver denominations still remain in use for bookeeping matters. Thus, when the Arab silver coin with its characteristic appearance inspired by the flat shaped drachmē of Sassanian coinage ${ }^{42}$ was put in circulation, nolens-volens its name too

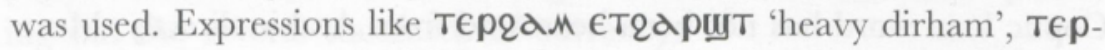

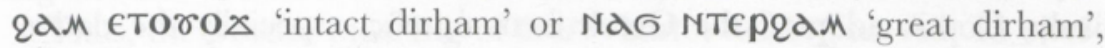
all refer to certain qualities and emissions of the coin, ${ }^{43}$ likewise occuring in Arabic papyri. ${ }^{44}$

Apart from these two words, only a few Arabic expressions are sporadically attested in Coptic legal documents up to the ninth century, such as (גА)Лдpd 'receipt', ${ }^{45} \Delta \gamma \mathbf{N}$ 'debt of money', ${ }^{46}$ (dג)-

${ }^{41}$ A. Grohmann, Einführung und Chrestomathie zur arabischen Papyruskunde, Prague 1955, 184f.; W. C. Schultz, "The Monetary History of Egypt 642-1517," in C. F. Petry (ed.), The Cambridge History of Egypt, Vol. I: Islamic Egypt, 640-1517, Cambridge 1998, 318-38.

${ }^{42}$ Grohmann, Einführung und Chrestomathie, 203-6; Schultz, "Monetary History."

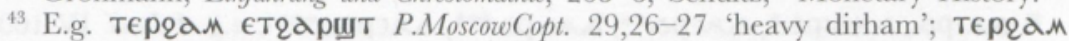

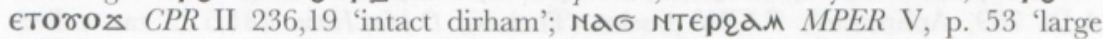
dirham'.

${ }^{44}$ Cf. Grohmann, Einführung und Chrestomathie, 213; M. C. Bates, "Coins and Money in the Arabic Papyri," in Y. Raghib (ed.), Documents de l'Islam médiéval. Nouvelles perspectives de recherche, Cairo 1991, 43-64.

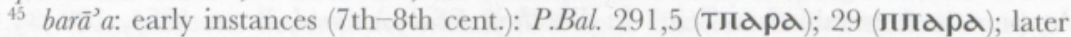

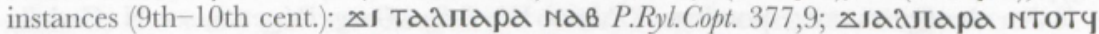
P.CrumVC 49,13; таגлара P.CrumVC 115,9.

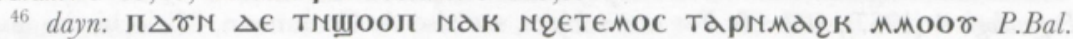
102,14-15, "the debt, we are willing for you to pay it to you in full." 


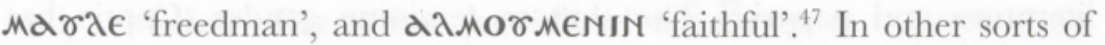
documentary texts like letters and lists, some other Arabic designations are attested. ${ }^{48}$ But, obviously, at that time the language contact between Arabic and Coptic speakers was mostly mediated by professional interpreters coming into contact with each other at a few tangential points of contact between two linguistically homogenous milieux, so that interference phenomena failed to appear in the written Coptic language, and even in the written language of daily use.

\section{The Late Coptic Teshlot Archive and Its Arabic Borrowings}

An advanced state of language contact has been revealed to us by the late Coptic legal documents of the Teshlot archive, containing nine contracts concerning the property of a man called Raphael son of Mina, who flourished in the first half of the eleventh century at Dashlūt. ${ }^{49}$ The scribes of these records regularly made use of at least four Arabic loanwords.

The word daмгрєт is the Arabic noun al-mīrath 'inheritance', ${ }^{50}$ an old-established Arabic legal term ${ }^{51}$ well known from both juridical

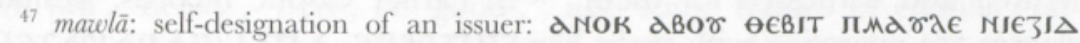
CPR IV 111,1; CPR IV, 168 c,e. mu'mininn: e.g. P.Bal. 187,7; 287,1.4; also attested in Greek documents, cf. CPR XXII (ed. F. Morelli), passim.

48 E.g. Naвака 'expenses' (PERF no. 603); Taабоrмaє 'the total amount' (MPER V,56); талкамтрє 'the bridge' (CPR II 228,7r); лаגм(н)мсна 'the station' (P.Crum VC 49,4.8).

49 T. S. Richter, "Spätkoptische Rechtsurkunden neu bearbeitet (II): Die Rechtsurkunden des Teschlot-Archivs," J7P 30 (2000), 95-148.

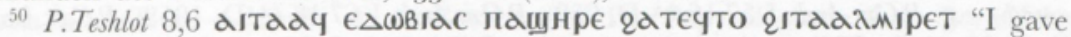

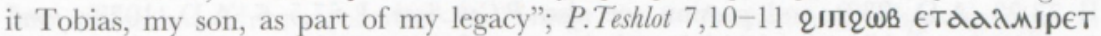
"concerning the matter of my inheritance"; M. Green, "A Private Archive of Coptic Letters and Documents from Teshlot," Oudheidkundige Mededelingen (Rijksmuseum van Oudheden, Leiden) 64 (1983), 108 f., considered the two Arabic loan words daмıєт

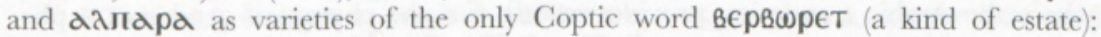
"If далгра and дамгрєт are Arabic words, it seems strange that the Coptic article should qualify the noun concerned when the Arabic article is already present." But already L. Stern ("Fragment eines koptischen Tractates," 117) observed that Arabic nouns "meist mit dem arabischen Artikel al . . . ins Koptische herübergenommen sind." L. S. B. MacCoull, "The Teshlot Papyri and the Survival of Documentary Coptic in the Eleventh Century," Orientalia Christiana Periodica 55 (1989), 204, suggests mīra "supplies" (root MYR; mār: I \& IV 'to make provision'), but this word is not suitable either semantically or phonetically. Arabic feminine nouns in Coptic never bear the ending $-\boldsymbol{T}$ but always $-\epsilon$ or $-\mathbf{\alpha}$.

${ }^{51}$ A. Layish, "Mīrāth," in EI $2: 106-112$; A. J. Wensinck and J. H. Kramers, "Mīrāth," in Handwörterbuch des Islam, Leiden 1941, 511-17. 
literature and papyri. ${ }^{52}$ The shift to feminine gender (Coptic has T-dגм.рєT) may be due to the semantic vicinity of an earlier Coptic expression of 'inheritance', the Greek loan word канромомга which has been replaced by дамгрєт at least in the language of documents. ${ }^{53}$ Sarah Clackson was kind enough to draw my attenion to the contemporary Coptic account book BL Or. 13885 (to be published by her) wherein the same loan word is attested in a quite sim-

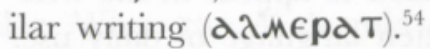

The meaning of the word daedT can be understood by its context. ${ }^{55}$ In clauses recording the bordering neighbours of an estate, obviously the word means something like 'border (of an estate)'. Thus, it is not so difficult to suggest the Arabic noun al-hadd as its etymon. The latter was commonly used in relevant clauses of contemporary Arabic sales of estates and the like. ${ }^{56}$ To the best of my knowledge, the loanword da\&dT is hitherto attested in Coptic in the Teshlot archive only. But here, the term has entirely replaced the former term Tow used in earlier Coptic records.

The word aммогр is also comprehensible by means of contextual connotation. It usually occurs as a verbal expression in a clause where the scribe accounts for his assistance to an issuing person being unable to write: "They have instructed ( $\boldsymbol{\alpha}$ ммогр) me, I have written and witnessed for them." ${ }^{57}$ In earlier Coptic records, similar

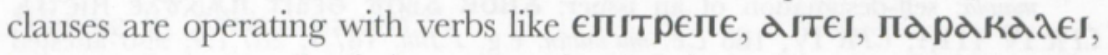
кшрш, хмог, all of them meaning 'to instruct, to request some-

${ }^{52}$ For instance, in certain security clauses excluding claims to an inheritance (bimīrāth), e.g. P.Cair.Arab. I 57,16 (A.D. 952), P.Cair.Arab. I 67,18 (A.D. 1058), P.Cair.Arab. II 73,23 (A.D. 932), and passim; see also P.Cair.Arab. I 67,5-6 (A.D. 1058): jamtr haqqihi min mürthihi min abīhi "the whole part of that which he inherited from his father."

${ }^{53}$ In literature, the word канромомга continued to be used, cf. Triadon 516,3 (where the Arabic translation provides mīrāth). For the change of gender as a phenomenon of language contact, see P. Nagel, "Die Einwirkung des Griechischen auf die Entstehung der koptischen Literatursprache," in F. Altheim and R. Stiehl, Christentum am Roten Meer, Berlin/New York 1971, 337-44.

${ }^{54}$ Fol. 17B,1.

55 E.g. P.Teshlot 2,8 мaI мє мадедт єліні тнру "these are the borders of this whole house"; P.Teshlot 3,15-16 ладедт мпнч ... ладедт мєент "the eastern border ... the northern border."

56 E.g. P.Cair.Arab. I 53 (9th cent.) lines 8, 15, and 19.; P.Cair.Arab. I 54 (A.D. 1056), lines 4, 5; and passim.

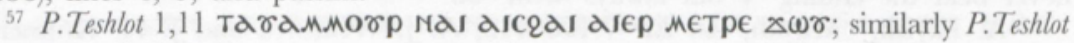
1,$3 ; 3,18 ; 4,17 ; 5,15$. 
body'. Michael Green has considered dммогp a variety of the Coptic verb могp 'to bind, to tie', suspecting an idiomatic meaning 'to involve, to oblige'. ${ }^{58}$ But there are two reasons to doubt his opinion. First, the word under discussion is permanently written aммогр; second, its grammatical object always appears together with the dative particle, unlike the transitive verb могp 'to bind' which requires a direct object. That is why I consider aммогp to be rather a borrowing depending on Arabic amara 'to command, to instruct', a verb developing the imperfect vocal $u$, e.g. ya'mur 'he commanded'. In the Coptic spelling, the glottal stop, properly being the final consonant of the first syllable, was analyzed as a gemination of the sonorant $/ \mathrm{m} /$. The prefixed conjugation pattern may have been the reason for adopting the Arabic imperfect stem. In Arabic papyri, relevant clauses contain the related noun amr 'order, instruction'. ${ }^{59}$

The word dTTde€pI appears in connection with amounts of money. In P.Teshlot 2, the payment for a house is acknowledged by the words: "gold 8 holokottinos $€$ NaTTd $€$ p I I did receive by him." In P.Teshlot 5, the price of a building was fixed: "gold (pieces) 9 Natderp€I." ${ }^{60}$ Presumably, the word functions as an attribute of gold currency. In Arabic papyri we meet, apart from attributes like 'in full', 'heavy', 'new', or 'good', ${ }^{61}$ also some names of caliphs converted into adjectives with the nisba ending, thus indentifying certain dìnār emissions by the holder of the minting prerogative. ${ }^{62}$ Among

${ }^{58}$ Green, "A Private Archive," 10.

59 "On his instructions (bi-amrihi) he has written," e.g. P.Hamb.Arab. 1,25 kataba 'anhu bi-amrihi wa-mahdarihi; cf. A. Grohmann, "Die Papyrologie in ihrer Beziehung zur arabischen Urkundenlehre," in Vorträge des 3. Internationalen Papyrologentages in München vom 4.-7. September 1933, Münchener Beiträge zur Papyrusforschung und antiken Rechtsgeschichte 19, München 1934, 348. Re the problems of verb borrowing from Arabic to Coptic, see generally T. S. Richter, "Arabic loan-words in Coptic."

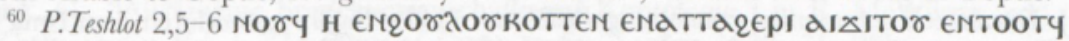
"gold 8 holokottinos of al-Zāhir, I have received them from him"; P.Teshlot 5,10

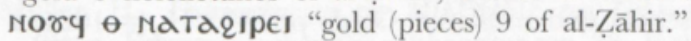

${ }^{61}$ Cf. Grohmann, Einfuihrung und Chrestomathie, 200-2.

${ }^{62}$ Instances without the article: dīnār mustansiñ 'dinar of al-Mustansir' (r. 427-87/ 1036-94) P.Cair.Arab. I 45,6; 64,14; 66,13; 71,16-17; P.Berl. 8169,4; 8217,4; 9160,7; 15022,5; dīnār mu'izzì 'dinar of al-Mu'izz' (r. 341-365/953-975); cf. P.Cair.Arab. I, p. 203, and Grohmann, Einführung und Chrestomathie, 197 n. 2.; instances with article: R. G. Khoury, Chrestomathie de la papyrologie arabe, HdO I, 2/2, Leiden/New York/ Copenhagen/Köln 1993, no. 54 (A.D. 1054), line 10: min al-ayn al-mu'izzī "d'or d'al Mu'izz"; no. 53,11 (= BAU no. 10, A.D. 1015); P.Cair.Arab. II 111,2: al-hākimē "(dinars of al-Hakim). 
them there is attested the name of the Fatimid caliph 'Alī al-Zāhir (r. 411-427/1021-1036). ${ }^{63}$ So, I consider dTTd\&€pI a transcription of the attribute al-zāhinī, denoting dīnārs struck under the authority of al-Zāhir. P.Teshlot 2 and 5 both date from the time of his rule.

Except for the last one, the Arabic loanwords attested in the legal documents of the Teshlot archive are principally translatable terms. Moreover, all of them are important legal terms, each of them replacing Coptic or Greek terms of the earlier Coptic juridical language. In comparison with the evidence of early attested Arabic loanwords, we observe quite a different state of affairs. The sociolinguistic evidence available from these observations seems to indicate a permanent language contact between Arabic and Coptic speakers in the field of private law, that is, in the midst of everyday life. A similar conclusion is pointed out by the increasing number of bilingual private documents since the mid-ninth century, ${ }^{64}$ as well as by tenthcentury Arabic contracts settled by two Christian parties, as shown by Nabia Abbott in 1941. ${ }^{65}$ Last, but not least, lexicological evidence corresponds to formulary evidence, since there is an obvious influence of Arabic formularies and phrases on the wording of late Coptic records. ${ }^{66}$

\section{Bibliography}

Abbott, N., "Arabic Marriage Contracts among Copts," Zeitschrift der Deutschen Morgenländischen Gesellschaft 95 (1941), 59-81.

Arjava, A., Women and Law in Late Antiquity, Oxford 1998.

${ }^{63}$ Grohmann, Einführung und Chrestomathie, 197, wrote: "Aus der langen Reihe von Goldprägen der Fāțimidenkalifen sind ausser jenen des al-Mu'izz nur die des Kalifen al-`Azīz billāh (976-996 n.Chr.), al-Hākim bi-amr Allāh (996-1021 n.Chr.) und alMustanșir billāh (1036 bis 1094 n.Chr.) in den Papyri erwähnt." But already J. Karabacek commented concerning PERF no. 1147: "Sigill ..., wodurch dem Isma'î,, Clienten des Isma'îl, auf Grund des von ihm aufgeführten Bauwerkes die Geldsteuer sammt Wägegebühr in hâkimitischem und zâhirischem Golde pro 415 H. (= 1024/5 n.Chr.) berechnet wird. Ausgefertigt im Scha'bân des Jahres 416 H. (= SeptemberOktober 1025 n.Chr.)." (Italics by T.S.R.)

${ }^{64}$ As for legal documents, see T. S. Richter, Rechtssemantik und forensische Rhetorik. Untersuchungen zu Wortschatz, Grammatik und Stil der Sprache koptischer Rechtsurkunden, Kanobos 3, Leipzig 2002.

${ }^{65}$ N. Abbott, "Arabic Marriage Contracts among Copts," Zeitschrift der Deutschen Morgenländischen Gesellschaft 95 (1941), 59-81.

${ }_{66}$ Cf. Richter, "Arabische Lehnworte," 82-5, and idem, "Spätkoptische Rechtsurkunden neu bearbeitet (III): P.Lond.Copt I 487 - arabische Pacht in koptischem Gewand," JfP 33 (2003), forthcoming. 
Bates, M. C., "Coins and Money in the Arabic Papyri," in Documents de l'Islam médiéval. Nouvelles perspectives de recherche, Cairo 1991, 43-64.

Berger, A., "Wohnungsmiete und Verwandtes in den gräko-agyptischen Papyri," in Zeitschrift für vergleichende Rechtswissenschaft 29 (1913), 321-415.

Bouriant, P., "Fragment d'un manuscrit copte de basse époque ayant contenu les principes astronomiques des arabes," fournal Asiatique, deuxième série, tome IV, Paris 1904, 117-23.

Cadell, H., "Nouveaux fragments de la correspondence de Kurrah ben Sharik," Recherches de Papyrologie 4 (1967), 107-60.

Chassinat, É., Un papyrus médical copte, Mémoires publiés par les membres de l'Institut français d'archéologie orientale du Caire 32, Cairo 1921.

Crum, W. E., Coptic Ostraca, London 1902.

- Short Texts from Coptic Ostraca and Papyri, Oxford 1921.

Depuydt, L., "Eight Exotic Phenomena of Late Egyptian Explained," in K. Ryholt (ed.), Acts of the Seventh International Conference of Demotic Studies, Copenhagen, 23-27 August 1999, CNI Publications 27, Copenhagen 2002.

Drescher, J., “A Coptic Calculation Manual,” BSAC 13 (1948-49), 137-60.

Emmel, S., "Proclitic Forms of the Verb + in Coptic," in D. W. Young (ed.), Studies Presented to Hans Jakob Polotsky, E. Gloucester (Mass.) 1981, 131-46.

Erman, A., Bruchstücke koptischer Volkslitteratur, Berlin 1897.

Gardner, I., A. Alcock, and W.-P. Funk, Coptic Documentary Texts from Kellis, Dakhleh Oasis Project Monograph 9, Oxford 1999.

Green, M., "A Private Archive of Coptic Letters and Documents from Teshlot," Oudheidkundige Mededelingen (Rijksmuseum van Oudheden, Leiden) 64 (1983), 61-122.

Grohmann, A., "Der Beamtenstab der arabischen Finanzverwaltung in Ägypten in früharabischer Zeit," in Festschrift Friedrich Oertel, Bonn 1964, 120-34.

—- Einführung und Chrestomathie zur arabischen Papynuskunde, Prague 1955.

- "Griechische und lateinische Verwaltungstermini im arabischen Ägypten," CdE 13-14 (1932), 275-84.

— , "Die Papyrologie in ihrer Beziehung zur arabischen Urkundenlehre," in Vorträge des 3. Internationalen Papyrologentages in München vom 4.-7. September 1933, Münchener Beiträge zur Papyrusforschung und antiken Rechtsgeschichte 19, München 1934, 327-50.

Hasitzka, M. R. M., and H. Harrauer, Neue Texte und Dokumentation zum KoptischUnterricht, MPER n.s. 18, Vienna 1990.

Junker, H., Koptische Poesie des 10. Jahrhunderts, Teil 1-2, Berlin 1908-11.

Layish, A., "Mīrāth," in Encyclopédie de l'Islam, nouvelle édition, tome VII, Leiden/New York/Paris 1993, 108-15.

von Lemm, Oskar, Der Alexanderoman bei den Kopten, St. Petersburg 1903.

von Lieven, A., Der Himmel über Esna, ÄA 60, Wiesbaden 2000.

MacCoull, L. S. B., "The Teshlot Papyri and the Survival of Documentary Coptic in the Eleventh Century," Orientalia Christiana Periodica 55 (1989), 201-6.

Mink, G., "Allgemeine Sprachwissenschaft und Koptologie," in R. McWilson (ed.), Coptic Studies Vol. I: The Future of Coptic Studies, Leiden 1978, 71-103.

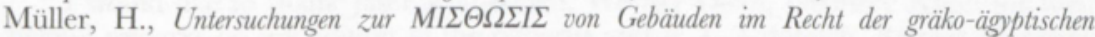
Papyri, Erlanger Juristische Abhandlungen 33, Köln/Berlin/Bonn/Munich 1985.

Nagel, P., "Die Einwirkung des Griechischen auf die Entstehung der koptischen Literatursprache," in F. Altheim and R. Stiehl, Christentum am Roten Meer, Berlin/New York 1971, 337-44.

Richter, T. S., "Alte Isoglossen im Rechtswortschatz koptischer Urkunden," Lingua Aegyptia 10 (2002), 389-99.

_ "Arabic Loan-Words in Coptic" in K. Versteegh (ed.), Encyclopaedia of Arabic Language and Linguistics, forthcoming.

, "Arabische Lehnworte und Formeln in koptischen Rechtsurkunden," J7P 31 (2001), 75-98. 
— - "Koptische Mietverträge über Gebäude und Teile von Gebäuden," fffP 32 (2002), 113-68.

-, Rechtssemantik und forensische Rhetorik. Untersuchungen zu Wortschatz, Grammatik und Stil der Sprache koptischer Rechtsurkunden, Kanobos 3, Leipzig 2002.

, "Spätkoptische Rechtsurkunden neu bearbeitet (II): Die Rechtsurkunden des Teschlot-Archivs," f7P 30 (2000), 95-148.

— , "Spätkoptische Rechtsurkunden neu bearbeitet (III): P.Lond.Copt. I 487 arabische Pacht in koptischem Gewand," JfP 33 (2003), forthcoming.

Rubenson, S., "Translating the Tradition: Some Remarks on the Arabization of the Patristic Heritage in Egypt," Medieval Encounters: Jewish, Christian and Muslim Culture in Confluence and Dialogue 2 (1996), 4-14.

Schultz, W. C., "The Monetary History of Egypt 642-1517," in C. F. Petry (ed.), The Cambridge History of Egypt, Vol. I: Islamic Egypt, 640-1517, Cambridge 1998, 318-38.

Stern, L., "Fragment eines koptischen Tractates über Alchimie," ZÄS 23 (1885), 102-19.

Till, W. C., Die koptischen Rechtsurkunden aus Theben, Vienna 1964.

Weinreich, U., Languages in Contact, The Hague/Paris 1968.

Wensinck, A. J., and J. H. Kramers, "Mīrāth," in Handwörterbuch des Islam, Leiden 1941, 511-17.

Worp, K. A., "Bemerkungen zur Höhe der Wohnungsmiete in einigen Papyri aus dem byzantinischen Ägypten,” Tyche 3 (1988), 273-5.

Worrell, W. H., Coptic Sounds, Ann Arbor 1934. 